\title{
Trasímaco E A TÉCHNE Do gOVERNo
}

\author{
Luiz Mauricio Bentim da Rocha Menezes ${ }^{1}$
}

\begin{abstract}
Resumo: Ao associar governo à téchne, Trasímaco estabelece que o governo também exige um conhecimento específico. Esse saber permitiria que o governante pudesse beneficiar-se dos governados, tirando proveito deles. Em sua definição de governo, ele aproximará essa téchne do governo ao governante injusto, mais especificamente o tirano. Neste trabalho, pretende-se analisar a relevância dos argumentos de Trasímaco para a filosofia política.
\end{abstract}

Palavras-Chave: Trasímaco. Sócrates. Governo. Téchne. Filosofia Política.

No Livro I da República de Platão², a maneira pela qual Sócrates e Trasímaco entendem a téchne do governante leva a tipos de governos diferentes. Há entre os dois uma clara disputa entre quem é, de fato, o verdadeiro governante: o justo (defendido por Sócrates) ou o injusto (defendido por Trasímaco). Tal disputa deve ser também resolvida no campo epistêmico, pois Trasímaco pretende mostrar a possibilidade de uma téchne da tirania para governar a cidade. Aquele que conseguir demonstrar qual é, realmente, o verdadeiro governante, estará também provando que tipo de governante é o verdadeiro detentor da téchne do governo e que poderá, com isso, ser chamado de "mais forte". Se as premissas de Sócrates forem totalmente aceitas e a conclusão obtida for de que

\footnotetext{
${ }^{1}$ Professor de Filosofia, Ética e Política no Instituto Federal de Educação, Ciência e Tecnologia do Triângulo Mineiro (IFTM), Uberaba, MG - Brasil. (D) https://orcid.org/0000-0003-4925-9876 E-mail: lmbrmenezes@yahoo.com.br

Doutor em Filosofia pela UFRJ.

2 Para a traduçáo, utilizaremos o texto de Maria Helena da Rocha Pereira A República (Lisboa: Fundação Calouste Gulbenkian, 2001). Tomaremos essa tradução como base para nosso trabalho, usando traduçóes nossas, quando julgarmos necessário. Demais referências à 'República' serão abreviadas por Rep. indicando-se em seguida a numeração. Para o original grego em todo o trabalho, empregaremos o texto estabelecido por S. R. Slings, Platonis Rempublicam (Oxford: Oxford University Press, 2003).
}

http://dx.doi.org/10.1590/0101-3173.2019.v42n2.02.p9 
o governante enquanto artífice visa à conveniência/utilidade do governado, então, esse governante só pode ser justo. Tomado dessa maneira, o tirano de Trasímaco não pode ser considerado um verdadeiro governante, pois este age em seu próprio benefício. Trasímaco, assim, só poderia apontar uma prática que ocorre nos governos, uma tese descritiva da justiça e da injustiça, mas não poderia defender o governante injusto como verdadeiro governante.

Em seu artigo publicado em 1947, Kerferd irá coletar as principais posiçóes, atribuídas pelos comentadores ao discurso de Trasímaco. Seriam estas: ${ }^{3}$

I. Obrigação moral não tem existência real, mas é uma ilusão na mente dos homens (niilismo ético).

II. Obrigação moral não tem existência à parte de decretos legais (legalismo).

III. Obrigação moral tem existência real independente e surge da natureza do homem (direito natural).

IV. Os homens sempre perseguem o que eles pensam ser seu próprio interesse e devem fazê-lo a partir de sua própria natureza (egoísmo psicológico).

A única dessas posiçôes aceitas por Kerferd é a (III). Para refutar as outras posiçóes e justificar a terceira, ele irá propor que a justiça como sendo a conveniência do mais forte não pode ser tomada como definição, mas somente a justiça como sendo um bem alheio, entendendo que esta seria a real posição de Trasímaco (KERFERD, 1976, p. 560). Dessa forma, Kerferd propóe que a defesa de Trasímaco da injustiça coloca esta como uma obrigação moral para ele, assim como a justiça é uma obrigação moral para Sócrates. Com isso, Kerferd refuta a posição (I). (KERFERD, 1976, p. 561).

A identidade entre dikaion e nómimon, entendendo nisso uma concepção da justiça como observância das leis, estaria profundamente enraizada na cultura grega (VEGETTI, 1998, p. 241)4. No entanto, o posicionamento de Trasímaco sobre a justiça não pode unicamente ser defendido como "obediência às leis", pois, se assim fosse, a sugestão de Clitofonte seria aceita como solu-

${ }^{3}$ KERFERD, G. B. The Doctrine of Thrasymachus in Plato's Republic. Durham University Journal, v. 9, p. 19-27, 1947, reimpresso in: CLASSEN, C. J. (ed.). Sophistik. Wege der Forschung, band 187, Darmstadt: Wissenschaftliche Buchgesellschaft, 1976, p. 545-563 (as citações seguem a última paginaçáo).

${ }^{4}$ In: XENOFONTE, Memoráveis, IV. 4; Sócrates atesta a relação da justiça com a lei. 
ção para seu argumento. Clitofonte sugere aos demais que a lei feita pelo mais forte (governante) é o que ele julga ser sua conveniência, e esta deve ser seguida pelos mais fracos (governados) (Rep., 340a-b). Todavia, tal consideração não é aceita pelo próprio Trasímaco (Rep., 340c). A recusa de Trasímaco à sugestão de Clitofonte dá base para a refutação de Kerferd à posição do legalismo (II) defendida por Hourani (KERFERD, 1976, p. 561).

Quanto à posição (IV), Kerferd a refuta, dizendo que, em sua defesa da injustiça, Trasímaco recomenda que os homens ajam pelos seus próprios interesses, porém, os governados, ao contrário, agem ingenuamente, porque não buscam o próprio interesse, mas fazem o interesse do governante. Isso não condiz com o egoísmo psicológico, o qual defende que os homens perseguem sempre o próprio interesse (KERFERD, 1976, p. 562).

Refutadas as posições (I), (II) e (IV), Kerferd irá advogar a favor da posição (III), inserindo no argumento de Trasímaco a teoria do direito natural. Segundo Kerferd, Trasímaco tomaria como regra geral para a justiça o "bem alheio" (KERFERD, 1976, p. 559) e defenderia um ideal moral de injustiça que se opóe à justiça. ${ }^{5}$ Apesar de não usar a terminologia que opóe lei à natureza, Trasímaco tomaria a injustiça como uma areté e, com isso, faria da injustiça a realização da natureza dos homens (KERFERD, 1976, p. 562). Voltaremos a esse ponto mais à frente, em nosso trabalho, para uma melhor análise da proposta final de Kerferd.

Chappell, em seu artigo, ${ }^{6}$ defende que há apenas uma tese descritiva em Trasímaco e não uma tese prescritiva. Para isso, tentará provar que Trasímaco náo utiliza os termos vício e virtude nem para a justiça nem para a injustiça. A injustiça seria a característica do homem virtuoso e excelente, mas sem ser ela mesma o caráter principal que faz dele um homem virtuoso (CHAPPELL, 1993, p. 9). Concordamos com Chappell que há uma tese descritiva em Trasímaco, no entanto, o que não aceitamos em Chappel é que não haja distinção entre vício e virtude, nos argumentos defendidos por Trasímaco. Ao referir-se ao governante como artífice que não erra no exercício de sua função, Trasímaco também aproxima dessa definição o sábio (бopós) (Rep., 340e5). Se

${ }^{5}$ Kerferd (1947/1976, p. 561): "Para Trasímaco a injustiça é uma obrigação moral em todos os sentidos em que para Sócrates a justiça é uma obrigação moral."

${ }^{6}$ Chappell (1993, p. 4): "Eu irei argumentar que Trasímaco não tem uma tese prescritiva sobre a justiça, mas somente tem uma tese descritiva sobre a justiça.” Barney (2006, p. 45) concorda com Chappell, acrescentando que Trasímaco "está, de fato, pressupondo um lugar comum e uma concepção tradicional de justiça, famosamente estabelecida pelo antigo poeta Hesíodo em uma de suas obras centrais da tradição moral grega, Os trabalhos e os dias". 
tomarmos o sábio ligado ao argumento da infalibilidade do artífice, teremos

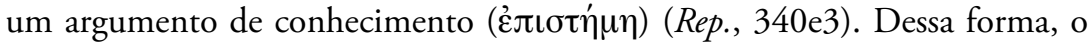
artífice tem um saber que o impede de errar e, se ele erra em algum momento, é porque esse saber o abandonou, não devendo ser chamado artífice aquele que se encontra nessa situação. A única maneira de manter o argumento de Trasímaco coerente seria a recusa dele da definição do governante como um artífice que visa à utilidade do governado, mantendo assim que o governante é um tipo especial de artífice que almeja sua própria utilidade. ${ }^{7}$ Esta seria a solução para manter o verdadeiro governante como sendo o mais injusto dos homens. Para fazer isso, Trasímaco terá de defender a injustiça como excelên-

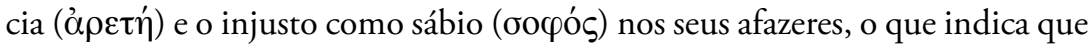
há também, nos argumentos apresentados por Trasímaco, uma tese prescritiva. Com o intuito de esclarecer esse ponto, Sócrates irá prosseguir com Trasímaco a discussão em torno do melhor tipo de vida: se é a injusta ou a justa (Rep., 347e et seq).

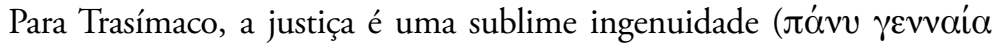

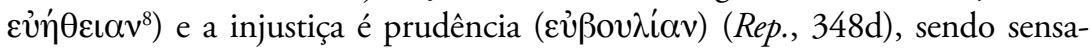

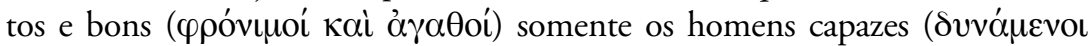
$\dot{\alpha} v \theta \rho \omega \dot{\pi} \omega v)$ de serem completamente injustos, com força para submeterem à sua autoridade as póleis (Rep., 348d). Ao tratar do homem com dýnamis para ser completamente injusto, Trasímaco está a aludir ao tirano. ${ }^{9}$ É este que simboliza seu verdadeiro governante, único capaz da mais completa injustiça. ${ }^{10}$ Como ele deixa bem claro, os outros tipos de injustiça "são por certo proveitosos, enquanto não descobertos. Mas não vale a pena falar deste assunto, mas sim daquilo de que há pouco fiz menção." (Rep., 348d). Entendemos, dessa maneira, a partir da própria colocaçáo de Trasímaco (acima citada), que, ao tratarmos de injusto, estaremos considerando agora o completamente injusto, i. e., o tirano. De acordo

\footnotetext{
${ }^{7}$ Alguns estudiosos da passagem defendem que nem toda arte tem como fim o benefício do seu objeto. Cf. Guthrie (2007, n. 65, p. 87); "Joseph (A. and M. Phil. 24 e 22) nota que Sócrates está certo ao afirmar que o propósito de uma arte como tal não é beneficiar o praticante, ainda que com ela ganhe a vida, mas errado em admitir que o propósito de todas as artes é beneficiar outros para os quais elas são exercidas. Um caçador exerce sua arte pela carne de caça, mas não em benefício dela, um dançarino por seu próprio corpo, que pode distender ou ferir para alcançar a perfeição"; Henderson (1970, p. 226) menciona "a arte da tortura".

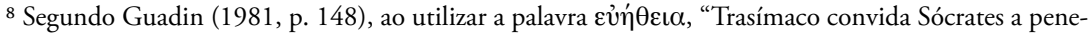
trar, como ele, no 'negativo' da justiça que é a lei real da política ateniense”.

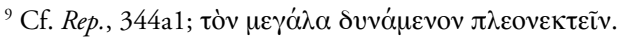

${ }^{10} \mathrm{O}$ homem capaz, no caso citado, é aquele que tem dýnamis suficiente para realizar a mais completa injustiça. Esse, como apontamos na nota anterior, só pode ser o tirano.
} 
com Trasímaco, somente esse tipo de injusto, capaz da mais completa injustiça, pode ser elevado ao estatuto de phrónimos e agathós.

O que precisa ficar clara aqui é a divisão da injustiça feita por Trasímaco. De um lado, temos a injustiça comum, do outro, temos a completa injustiça. Ambas são vantajosas e procuram tirar o máximo proveito de suas açóes, mas somente a última leva à felicidade. Duas passagens parecem suportar essa interpretação. Colocá-las-emos uma seguida da outra para fins explicativos:

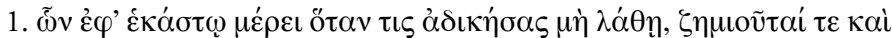

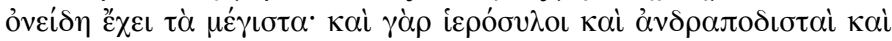

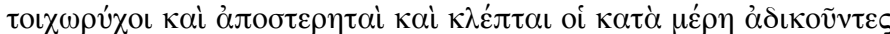

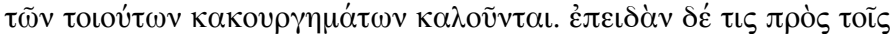

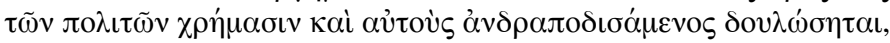

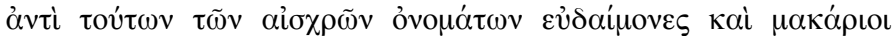

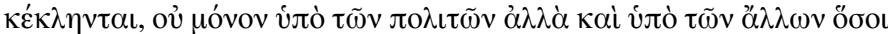

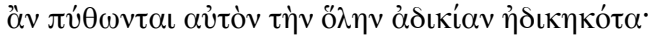

Se alguém cometer qualquer destas partes da injustiça não estando oculto, é castigado e recebe as maiores injurrias. Efetivamente, a quem cometer qualquer desses maleficios isoladamente, chama-se sacrilego, comerciante de escravos, gatuno, espoliador, ladrão. Mas se este, além de se apropriar dos bens dos cidadãos, faz deles escravos e os torna seus servos, em vez destes epitetos injuriosos, é qualificado de feliz e bem-aventurado, não só pelos seus concidadãos, mas por todos os demais que souberem que ele cometeu essa injustiça completa. (Rep., 344b1-c3).

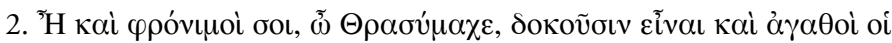
öठıког;

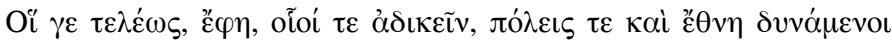

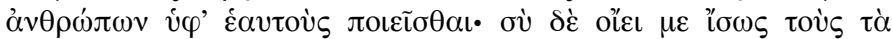

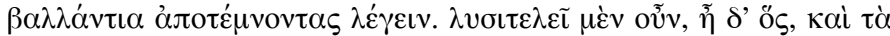

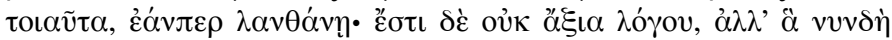
हैं $\lambda \varepsilon \gamma \mathrm{ov}$.

Acaso te parecem ser sensatos e bons os injustos, Trasimaco?

Sem dúvida, os que são capazes de ser completamente injustos, com força para submeterem cidades à sua autoridade. Julgas talvez que me refiro aos que tiram as bolsas de dinheiro. É que também isso é proveitoso, se passar despercebido. Mas não vale a pena falar do assunto, mas sim daquilo de que há pouco fiz menção. (Rep., 348d3-9). 
A definição geral de injustiça sublinha que se deve procurar a própria vantagem, com o intuito de se ter sempre mais do que o outro (Rep., 344c8-9). No entanto, há modos diferentes para se conseguir agir dessa forma. Ambas as passagens citadas sustentam uma divisão entre o injusto comum e o completamente injusto. $\mathrm{O}$ injusto comum deve agir ocultamente e, se for pego, será penalizado por isso, não podendo realizar o seu desejo, se náo estiver oculto à lei. $\mathrm{O}$ completamente injusto determina a lei e, portanto, não precisa ocultar-se a esta, mas a utiliza para realizar o seu próprio fim injusto, i. e., a sua própria vantagem. A distinção não é incoerente, apenas hierarquiza a injustiça, fazendo do tirano o único realmente feliz, ao realizar a injustiça, pois pode realizá-la plenamente. Isso nos faz ir contra a posição (III) de Kerferd, que defende a injustiça inerente à natureza humana. ${ }^{11}$ Primeiramente, não há nada a indicar que há em Trasímaco um desejo de injustiça em todos os homens. O que existe são homens injustos que agem por pleonexía. ${ }^{12}$. Depois, entre esses homens injustos, somente uma classe restrita é capaz de atingir a injustiça plenamente: são estes os tiranos. Quando Trasímaco aproxima a injustiça da excelência, está tratando apenas da completa injustiça, a qual é capaz de tornar felizes os homens que conseguem alcançá-la. Nisso, Trasímaco dará à injustiça todos os atributos normalmente dados à justiça, sendo bela e

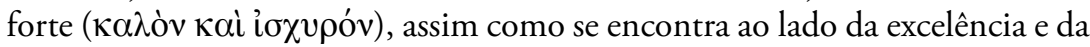

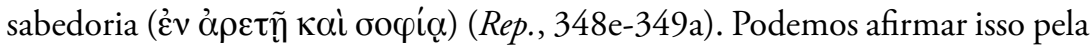
concordância de Trasímaco à pergunta de Sócrates sobre a excelência da injustiça, com um enfático "Adivinhaste a pura verdade." ('A $\lambda \eta \theta \dot{\varepsilon} \sigma \tau \alpha \tau \alpha \mu \alpha v \tau \varepsilon v ́ \eta)$ em 349a4. Dados esses pressupostos de Trasímaco, os quais Sócrates pretende investigar, eles irão concordar que

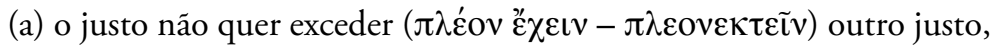

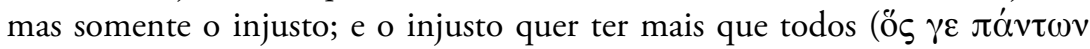
$\left.\pi \lambda \hat{\varepsilon}^{\prime} \mathrm{ov} \varepsilon^{\prime} \chi \varepsilon เ v\right)$; no que concluem que o justo não quer exceder o seu seme-

11 "Ele [Trasímaco] não usa a terminologia daqueles que opóe lei e natureza, mas sua equação da injustiça como virture (areté) demonstra que ele considera a injustiça como um cumprimento da natureza dos homens. Consequentemente, ele deve ser corretamente inserido entre os proponentes da teoria do direito natural." (KERFERD, [1947] 1976, p. 562, grifo nosso).

${ }_{12}$ Segundo Liddell e Scott (1883, p. 1224), a palavra $\pi \lambda \varepsilon o v \varepsilon \xi \xi \dot{\alpha} \alpha$ pode significar ganância, apego, arrogância, vantagem, abundância. De acordo com Chantraine (Dictionnaire Étymologique de La Langue Grecque. Histoire de Mots, tome III. Paris: Klincksieck, 1979, p. 913), a palavra pertence

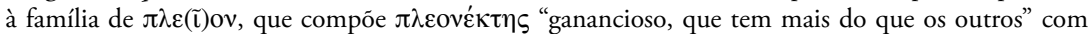
$-\varepsilon \kappa \tau \dot{\varepsilon} \omega$, - $\dot{\varepsilon} \kappa \tau \eta \mu \alpha,-\varepsilon \xi \xi \alpha$, etc., cf. s.u. "̌ $\chi \omega$. Pelo significado amplo da palavra e por ser peça-chave para se entender o tipo de desejo aqui tratado, preferimos pela sua transliteração e não pela tradução. Quando usarmos a palavra, em nosso trabalho, será no sentido de "desejo de ter mais do que os outros". 
lhante, porém, o seu oposto, ao passo que o injusto quer exceder tanto o seu semelhante como o seu oposto (Rep., 349b-d);

(b) cada um deles tem a qualidade daqueles com quem se parece (

(c) o artífice é bom naquilo que é sensato, e o não-artífice é mau na-

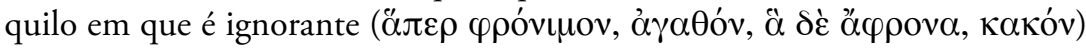
(Rep., 349e);

(d) em geral, todo artífice não pretende exceder seu semelhante, mas sim seu oposto, isto é, o não-artífice; e o não-artífice pretende exceder tanto o artífice como o não-artífice. Isso vale para toda espécie de conhecimento ou

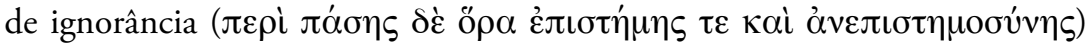
(Rep., 349e-350a);

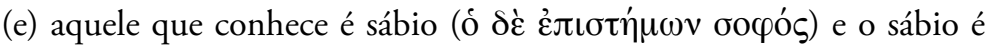

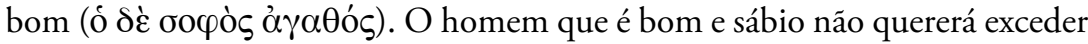
o que lhe é semelhante, mas sim o que é diverso; o homem que não conhece

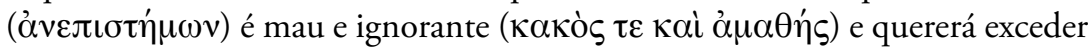
o que lhe é semelhante e o seu contrário (Rep., 350b);

(f) O justo se assemelha ao homem sábio e bom, e o injusto ao mau e ignorante. Como ambos concordaram que cada um tem as qualidades do que se assemelha, logo, o justo revela-se como bom e sábio, e o injusto, como ignorante e mau (Rep., 350c).

$\mathrm{O}$ argumento posto acima correlaciona téchne e epistéme, para distinguir o justo do injusto. Ao aproximar o justo do sábio e do bom, Sócrates se aproveitará disso para sustentar que ele e Trasímaco concordaram que a justiça é virtude e sabedoria ( кai oopíav) (Rep., 350d4-5). Podemos aceitar isso, se aproximarmos o bom do áristos, e assim teríamos uma relação da justiça com a areté.$^{13}$ Pelo que podemos entender do argumento, entre a justiça e a injustiça, aquela que receber os melhores atributos será classificada como areté e sophía (Rep., 349a), além de levar seu executor à felicidade. Tais atributos são os mesmos atribuídos aos artífices no exercício de sua arte, sendo estes: phrónimos, agathós, epistémon e sophós (Rep., 349e-350b). Todavia, Trasímaco claramente discorda do encaminhamento dado por Sócrates ao argumento, quando diz, em seguida:

${ }^{13}$ A palavra áristos possui o mesmo radical de areté, conforme demonstra Jaeger (2003, p. 26-28). 


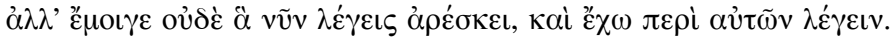

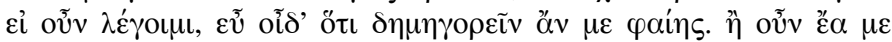

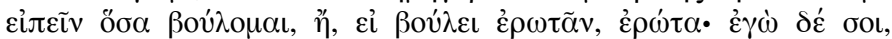

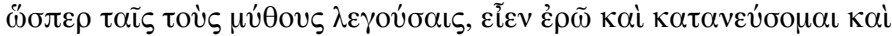

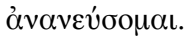

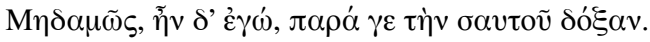

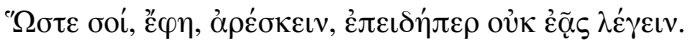

- [...] mas náo me agrada o que acabas de afirmar, e tenho o que contestar. Entretanto, sei muito bem que se eu tomar a palavra dirás que faço arenga. Deixe-me, pois, falar à vontade, ou, se desejas interrogar, interroga; e eu dirte-ei, como às velhinhas que estão a contar mitos, "seja", e farei com a cabeça que sim ou que não.

- Mas nunca - observei - contra a tua própria opiniäo.

- De maneira a poder agradar-te - retorquiu-, uma vez que não consentes que eu fale. (Rep., 350d8-e6).

Trasímaco parece ter-se tornado dócil a Sócrates, não estando mais disposto a argumentar contra este, já que Sócrates não permite que ele fale à sua maneira. O que pretendemos fazer, nesta parte de nosso trabalho, é dar uma resposta possível para tornar coerente a posição de Trasímaco frente à posição de Sócrates. Isso implica tornar mais clara a posição de Trasímaco em face dos argumentos de Sócrates e fazê-lo falar quando preferiu calar. Da maneira como vemos, a estrutura apresenta dois problemas não resolvidos, na discussão:

(a) $\mathrm{O}$ fato de um artífice dominar sua arte e, por isso, ser sábio, não está relacionado ao fato de ele ser justo. As justificativas de Trasímaco e de Sócrates náo partem do mesmo princípio para explicar por que o justo náo quer exceder o justo. Enquanto aquele diz que o justo náo excede o justo, "pois não seria refinado, como agora, nem de caráter simples" (oủ yò $\rho$ ồ

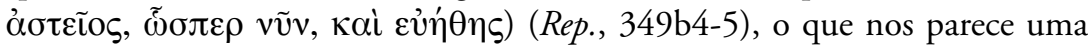
disposição de caráter inerente àquele que é justo, ${ }^{14}$ Sócrates irá defender que o justo não quererá exceder o justo, porque é conhecedor da sua arte. Dessa

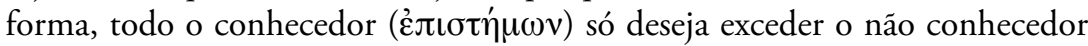
( $\alpha v \varepsilon \pi \iota \sigma \tau \eta \dot{\eta} \mu \omega v)$, enquanto este deseja exceder ambos. Entretanto, o argumen-

${ }^{14}$ É interessante notarmos a adoção de um termo ético por Trasímaco, para caracterizar a justiça. Trasímaco, dessa forma, está a afirmar que a deficiência da justiça em evitar a injustiça está no seu bom éthos de ser $(\varepsilon \dot{v}+\tilde{\eta} \theta o \varsigma)$, sendo o justo, por natureza, simples ou, até mesmo, ingênuo. Ao contrário, a injustiça é boa capacidade de escolher $(\varepsilon \dot{v}+\beta o v \lambda i ́ \alpha)$, sendo o injusto cauteloso e prudente em suas açōes. 
to socrático é falacioso, pois náo é correto afirmar que o conhecedor somente deseja exceder o não conhecedor. Nos jogos de soma zero, ${ }^{15}$ como xadrez, jogo de damas, boxe, tênis, lutas marciais, ambos os oponentes possuidores de epistéme tentam superar um ao outro. Esses exemplos são mais do que suficientes para provar que é possivel que um conhecedor queira exceder outro conhecedor de uma mesma arte. ${ }^{16}$ Isso não significa que o político deve ser um jogo de perda e ganho, mas que Trasímaco assim o entende e que a posição socrática náo refutou esse ponto, pois a mera opçáo de tomar outro caminho não é impossibilitar o primeiro caminho. Ou seja, Trasímaco entende que as coisas da pólis devem beneficiar aquele que detém o governo desta e, portanto, na medida em que o governante se beneficia (ganha), os governados se prejudicam (perdem). Isso torna a via trasimaqueana ainda válida, perante a posiçáo socrática, vide a existência de outras artes que se utilizam dessa mesma lógica de ganho e perda.

(b) Não fica claro por que o anepistémon, na sua ignorância, deseja exceder a todos. Por que um náo músico teria motivo para exceder o músico? $\mathrm{Ou}$ um não médico desejaria exceder o médico? É mais plausível aceitarmos que aquele que desconhece não deseje exceder os outros naquilo que é ignorante. Por exemplo, um lutador de boxe conhecedor da sua arte, porém ignorante em música, não irá querer exceder na arte da música um músico profissional, mas sim outro boxeador conhecedor igualmente da arte do boxe.

Santas aponta para a fraqueza da analogia de Sócrates, entendendo que pleonekteîn pode significar diferentes coisas, quando aplicado a justiça e a artes (SANTAS, 2006, p. 28). A aplicação para o termo seria diferente em Sócrates e em Trasímaco. "Em um caso nós temos a noção de fazer as coisas bem e fazê-las mal (as artes), no outro caso nós temos a noção de não ter mais coisas (justiça) e ter mais do que os outros (injustiça).” (SANTAS, 2006, p. 29). O

\footnotetext{
${ }^{15} \mathrm{Na}$ teoria dos jogos, um jogo de soma zero é um jogo cuja soma da utilidade obtida por todos os seus participantes, para cada combinaçấo de estratégias, sempre é igual a zero, isto é, um jogo no qual o que um jogador recebe é diretamente proporcional ao que os demais perdem.

${ }^{16}$ Apesar de Barney (2006, p. 53) apresentar o problema do argumento de Sócrates, nessa parte, ela irá defendê-lo, argumentando que "parte da solução é ver que pleonekteîn não é aqui simplesmente exceder em competição, mas maximizar a própria posse de algum bem em um contexto de soma zero - ter mais (pléon ékhein), que é, ou esforçar-se para ter mais, por virtude de alguém ter menos." Desse modo, Barney considera que Sócrates está correto em dizer que o desempenho de uma arte não é da ordem da pleonexía. Entretanto, consideramos a defesa de Barney insuficiente, pois obviamente há artes que são inerentemente competitivas, como o tênis, o xadrez ou as lutas, em geral, nas quais o objetivo é ter mais do que o outro no mesmo grau de correspondência em que o outro tem menos, sem levar em consideração que, em uma competição de verdade, o vencedor ganha o prêmio enquanto o perdedor o perde.
} 
excesso ( $\pi \lambda \lambda^{\prime}$ ov $\left.{ }^{\prime} \chi \varepsilon \varepsilon เ v\right)$ não nos parece um problema epistêmico, nos termos do argumento socrático, porém, deve ser resolvido nos próprios termos de Trasímaco. O que Trasímaco está a afirmar é que o injusto deseja exceder a todos, por ser conhecedor da sua arte. Como conhecedor da sua arte, o injusto náo poderia admitir que o fato de ele querer exceder a todas as pessoas seja sinal de ignorância, mas o contrário. $\mathrm{O}$ injusto tem a capacidade para exceder a todos os outros, por ser phrónimos, agathós, epistémon e sophós, sendo, dessa forma, um homem excelente e completo. A determinação de areté, portanto, tornou-se imprescindível para a defesa dos argumentos expostos, pois aquele que conseguir associar o seu argumento à areté poderá definir o seu governante como feliz. Devemos agora analisar se a analogia com a téchne é suficiente para garantir um argumento da justiça ou injustiça como areté.

Para que Trasímaco não seja refutado e mantenha o seu argumento coerente, ele teria que contra-argumentar, defendendo a possibilidade da existência de artífices que visam a sua própria conveniência, sendo o governante um deles; e dizer que aquele que conhece sua arte também pode querer a todos exceder, pois nada impede que o artífice conheça (tenha epistéme e sophía) e aja com injustiça, por considerar sua prática mais vantajosa. Se estivermos corretos em nossa investigaçáo, os argumentos de Sócrates foram, até o momento, insuficientes na refutação de Trasímaco, o que coloca ainda como possível a existência do tirano como o verdadeiro governante. Trasímaco entende que o governo deve ser mantido por uma téchne própria, que capacitaria o governante a bem administrar a cidade e a recolher para si todos os misthoi. Dessa forma, irá fazer a analogia do governante com um pastor e os governados como ovelhas, de maneira que o interesse do governante em governar é retirar o máximo proveito dos governados (Rep., 343b). A figura do pastor-governante é uma figura clássica da antiguidade (LIMA, 2007) e pode ser uma referência direta aos grandes reis que possuíam grandes domínios sob o seu poder. Para Trasímaco, será através do conhecimento de sua arte que um governante pode ser considerado um verdadeiro governante ( $\dot{\omega} \alpha \lambda \eta \theta \tilde{\omega} \varsigma$ ŏ $\rho \chi 0 v \sigma \iota v)$ (Rep., $343 \mathrm{~b} 5)$ e tirar para si todos os benefícios que levam à felicidade. Citemos como ele irá introduzi-lo:

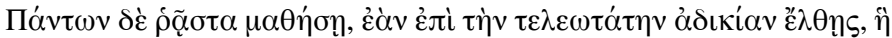

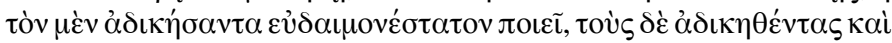

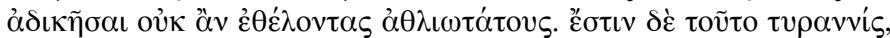

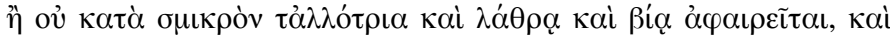

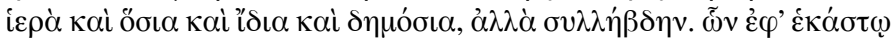

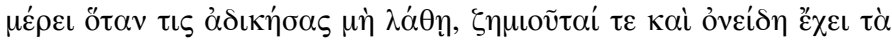




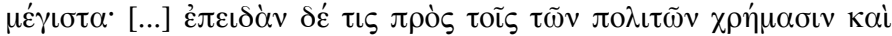

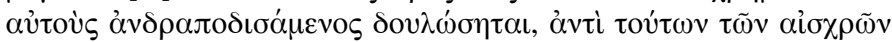

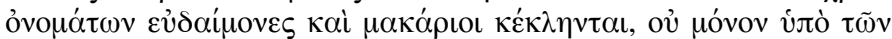

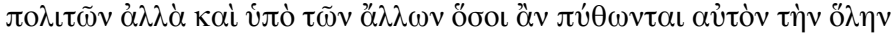

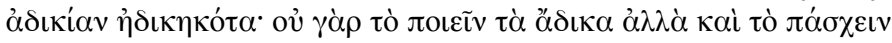

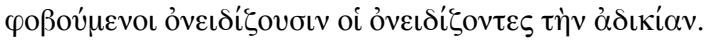

Mas a maneira mais fácil de aprenderes é se chegares a mais completa injustiça, aquela que dá o máximo de felicidade ao injusto, e a maior das desditas aos que foram vítimas de injustiças, e não querem cometer atos desses. Trata-se da tirania, que arrebata os bens alheios às ocultas e pela violência, quer sejam sagrados ou profanos, particulares ou públicos, e isso não aos poucos, mas de uma só vez. Se alguém cometer qualquer destas partes da injustiça não estando oculto, é castigado e recebe as maiores injúrias. [...] Mas se este, além de se apropriar dos bens dos cidadãos, faz deles escravos e os torna seus servos, em vez destes epitetos injuriosos, é qualificado de feliz e bem-aventurado, não só pelos seus concidadãos, mas por todos os demais que souberem que ele cometeu essa injustiça completa. É que aqueles que criticam a injustiça não a criticam por recearem praticá-la, mas por temerem sofrê-la. (Rep., 344a4-c4).

O tirano é visto como o verdadeiro governante, na visão de Trasímaco, pois permite a esse tipo de governante preocupar-se unicamente com o próprio benefício, podendo agir livremente com a injustiça. Com a introdução do tirano como paradigma do governante injusto, já podemos analisar melhor o raciocínio de Trasímaco sobre a função da justiça no governo. $\mathrm{O}$ tirano seria, para Trasímaco, aquele que melhor conciliaria a tese da justiça como um bem alheio com benefício do mais forte, pois (i) manda na cidade e, portanto, é o mais forte (Rep., 343c ), (ii) sendo o governante, faz as leis da maneira como lhe aprouver, (iii) obriga aos governados o cumprimento da justiça, de modo a poder beneficiar-se disso, e (iv) age livremente em benefício próprio. ${ }^{17}$

O grande dilema que envolve tudo isso é o seguinte: se o governante, como um artífice, é infalível na execução da sua função, ele deve entender o limite que exige a sua arte. Contudo, o injusto é aquele que tem a sua alma tomada pela pleonexía, o que faz com que ele aja sempre em busca da sua

\footnotetext{
${ }^{17}$ Klosko (1984, p. 11) e Everson (1998, p. 116-117) argumentam que há uma inconsistência nos argumentos de Trasímaco, devido à incompatibilidade da tese do bem alheio com as leis feitas pelo governante, pois, no caso do tirano, aquele que faz as leis seria o mesmo que as infringiria. Tais consideraçôes nada mais são do que uma reafirmação de uma definição legalista, em Trasímaco, porque reduziria a justiça a questốes de obediência às leis, somente. Chappell (2000, p. 101-107), em resposta, irá ressaltar que não há evidência de que Trasímaco espera que a justiça e a injustiça possam ser definidas somente em termos de obedientes à lei e seus opostos.
} 
vantagem, em detrimento dos outros. Como conciliar o limite da téchne de governar com o desejo ilimitado de "ter sempre mais" do injusto?

Penner defende que, ao elevar o discurso a um estatuto epistêmico do governante que náo erra, Trasímaco cria automaticamente uma ciência do governo (PENNER, 2009, p. 206-207). Como ciência ${ }^{18}$, a arte do governante deve seguir uma definição precisa, não podendo fazer menção a casos particulares (PENNER, 2009, p. 209). Analisando se é possível pensar em um governante que reúna os misthoi em seu próprio benefício, Penner discorda dessa possibilidade, pois haveria uma ciência híbrida, enquanto, pelo argumento de Sócrates, a arte dos lucros é uma arte à parte que se adiciona a outra arte (PENNER, 2009, p. 208). Mesmo que haja uma ciência geral de ganhar os próprios benefícios, ao governar tirando vantagem dos governados, tem-se ainda uma incoerência (PENNER, 2009, p. 210), ou seja, de que não há ciência do completamente injusto, pois, de acordo com Penner, a injustiça depende da justiça (PENNER, 2009, p. 213).

Mas o tirano é aquele que não apenas visa a seu próprio benefício, como aquele que controla a justiça dos governados. Nesse caso, o que Trasímaco está a dizer é que a justiça está subordinada à injustiça do governante, não o contrário, como pretendemos demonstrar.

É importante notar que a cena dramática claramente demonstra a insatisfação de Trasímaco, ao ter de responder a Sócrates e não poder falar como ele bem quiser. Quando Sócrates pede que Trasímaco não responda contra a própria opiniāo, ele responde: "De maneira a poder agradar-te, uma vez que não consentes que eu fale.” (Rep., 350e). É visível, nessa parte, que Trasímaco mantém o compromisso de manter um lógos comum aos dois, mas ele mesmo se sente contrariado de continuar nesses termos de pergunta e resposta e, em protesto, evita contrariar Sócrates. Partindo do ponto de que a justiça é excelência e sabedoria e a injustiça maldade e ignorância (Rep., 350d), Sócrates pretende investigar qual das duas teria maior capacidade e maior força

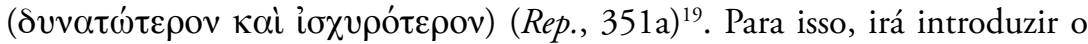
assunto da seguinte maneira:

\footnotetext{
${ }^{18}$ Penner parece utilizar a palavra ciência do mesmo modo que empregamos a palavra arte, referindose, dessa forma, ao termo grego téchne, o qual, no Livro I da República, aparece associado a epistéme.

${ }^{19}$ Como bem nota Araújo (2005, nota 29, p. 41, grifo nosso): "Ao dizer ser a injustiça mais forte, em

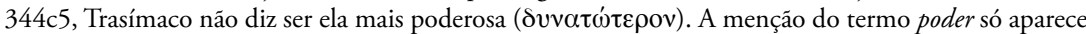
em 348d6-7, onde o sentido da injustiça completa é poder criar sob si cidades e etnias de homens

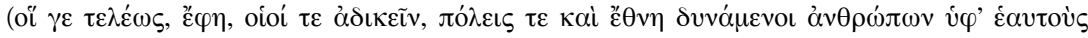

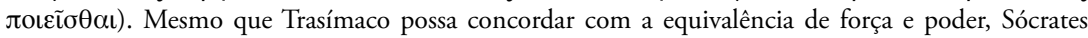




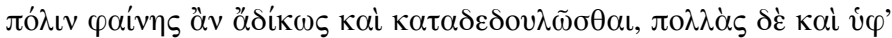

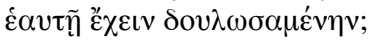

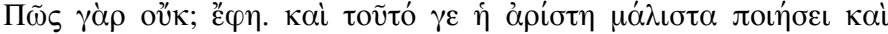

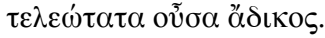

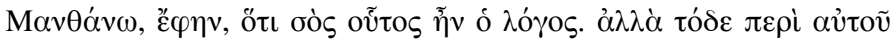

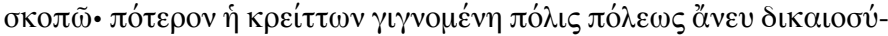

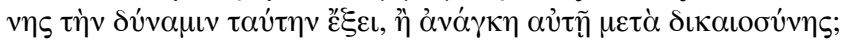

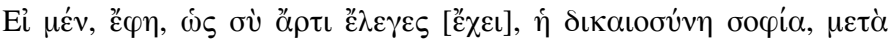

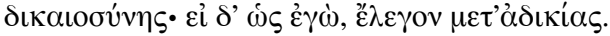

- Concordarias que seria injusto para uma pólis tentar submeter injustamente outras póleis e reduzi-las à escravatura?

- Como não? E isso é o que fará a melhor e a mais completamente injusta.

- Compreendo, pois este é o seu argumento. Mas, relativamente a ele, só quero examinar este ponto: uma pólis que se assenhoreia de outra pólis exercerá a sua dominação sem a justiça, ou será forçado a usar dela?

- Se é como há pouco afirmavas - a justiça é sabedoria - com a justiça. Mas se é como eu disse, com a injustiça. (Rep., 351b1-c2).

Trasímaco parece insatisfeito com o resultado da investigação passada, o que fica claro pela apresentação de dois caminhos possíveis para uma pólis dominar a outra: com justiça ou com injustiça. Não está claro ainda, para ele,

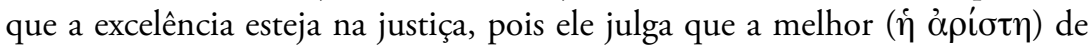
todas as póleis usará da injustiça para dominar as outras (ADAM, 2009, p. 55). ${ }^{20} \mathrm{O}$ não convencimento de Trasímaco é devido ao argumento falacioso de Sócrates em tentar definir a justiça como areté e sophia. Trasímaco julga que a injustiça, por sua própria força despótica, pode tomar todos os bens que deseja e fazer seu possuidor feliz. Desse modo, há um outro caminho por ele apresentado, mas que não é explorado pelos argumentos de Sócrates. O que Sócrates irá demonstrar é que, se o érgon da injustiça é causar o ódio onde quer que surja, fazendo com que aqueles que a possuam fiquem incapazes de empreender qual-

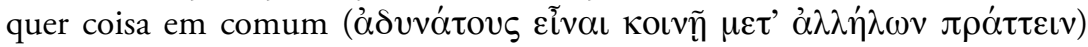

não o fará senão como um certo ardil de refutação. Na verdade, ele amplia o sentido desse poder, que a princípio seria uma caracterização da injustiça, para escapar da questáo da força. Como diz Adam

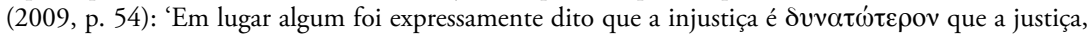
mas Kaì $\delta v v \alpha \tau \omega ́ \tau \varepsilon \rho o v$ foi acrescentado para ênfase', concluindo posteriormente (ADAM, 2009, p. 61): 'A única seção do diálogo ao longo da qual Sócrates passa em silêncio é a refutação do enunciado de que a injustiça é forte'."

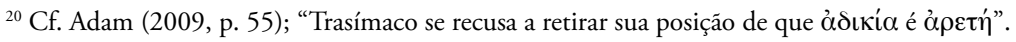


(Rep., 351d-e), então a injustiça não pode ser boa para aquele que a possui. Se considerarmos somente a injustiça entre os homens, estes viveriam em lutas e desavenças, sem nunca chegarem a um acordo. Tal efeito impossibilita qualquer tentativa de se estabelecer uma pólis. Sócrates defenderá que a injustiça não pode atuar sem a justiça, e nisto consiste a força da justiça (Rep., 352cd). Mas isso que é dito por Sócrates não vai contra o que expôs Trasímaco no início, pois, se bem entendemos a exposiçáo dos seus argumentos sobre a justiça e a injustiça, podemos ver que ele defende que o governante injusto deve governar com a justiça, nunca sem ela, já que os governados devem continuar a praticá-la para a manutençáo da ordem justa estabelecida na pólis e pelo benefício do governo encarnado na figura do governante. A justiça, nesse caso, é produto da injustiça do governante, que é quem faz as leis e determina com estas o justo, conforme Trasímaco parece defender com seu argumento do pastor-governante. ${ }^{21}$

O caminho que Trasímaco propóe para o argumento concilia lei e força. ${ }^{22}$ Tal relação não está em desacordo com a téchne do governo, a qual prevê o uso de ambas, quando necessário for. Se tais atributos também estáo em poder do governante injusto, ele pode-se valer tanto da lei como da força para determinar o justo para os demais. ${ }^{23} \mathrm{O}$ problema, dessa maneira, não está no governo, mas na alma do tirano. Como conciliar a pleonexía existente, por definição, em sua alma com a arte de governar?

Ousamos aqui uma hipótese para responder à questão. Um governante tem a capacidade para ter mais que todos os outros. Isso significa que ele se utilizará de todos os meios possíveis para conseguir o seu próprio objetivo. Em outras palavras, o governante sabe escolher o melhor meio para atingir os fins desejados, i. e., sua própria vantagem. Ter mais do que os outros implica saber como agir para tal fim e, portanto, exige um conhecimento (epistéme), sem o qual não se pode chegar à própria vantagem. A lei é um elemento importante

\footnotetext{
${ }^{21}$ Cf. Strauss (1964, p. 82, grifo nosso), que faz uma relação dessa passagem com a passagem da arte do pastor, argumentando que "isto talvez signifique uma admissão de que a justiça possa ser um mero meio, senão um indispensável meio, para a injustiça."

${ }^{22}$ Assinala Reeve (2008, p. 98): "A explicação de Trasímaco é uma combinaçấo coerente e engenhosa, portanto, de um realismo ético e um convencionalismo semântico, que identifica a justiça em cada cidade como sendo a conveniência do mais forte e um conteúdo semântico da 'justiça' com o que suas leis particulares prescrevem."

${ }^{23}$ Cf. Rep., 344a7-b1, em que Trasímaco diz que a tirania "arrebata os bens alheios a ocultas e pela violência, quer sejam sagrados ou profanos, particulares ou públicos, e isso náo aos poucos, mas de uma só vez."
} 
para a manutenção do tirano. Ele deve saber como fazer leis benéficas a si mesmo, porque, do contrário, não conseguiria manter-se no poder. Para isso, é necessário ter uma téchne que permita ao tirano fazer boas leis para determinar a justiça para os governados e, com isso, ele se possa manter no governo por uma quantidade maior de tempo. A força é igualmente uma das atribuiçóes do governante que pode ser usada a seu favor, caso haja necessidade. Sem uma téchne adequada, o tirano não pode atingir corretamente a sua conveniência e nem agir plenamente com a injustiça. Ao contrário dos outros injustos, os quais não podem agir senão ocultamente, a téchne do governo é o que permite ao completamente injusto ter sempre mais que os demais e ser, segundo Trasímaco, feliz e bem-aventurado.

A direçáo que o discurso irá tomar, ao prosseguirem o exame sobre a

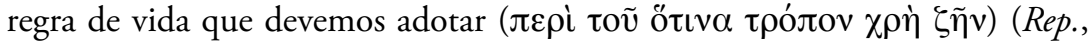
$352 \mathrm{~d}$ ), não foi bem desenvolvida por Sócrates, pois envolve alguns saltos argumentativos. Ao determinar que a função ("ع $\rho \gamma o v)$ de cada coisa é aquilo que ela executava mais belamente ( $\kappa \alpha \dot{\alpha} \lambda \iota \sigma \tau \alpha)$ do que as outras, ele conclui que parece ter uma excelência que lhe é própria tudo aquilo que está organizado para

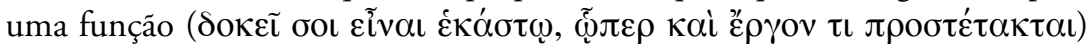
(Rep., 353a-b). Até o ponto aqui apresentado, ou seja, antes da introdução da alma por Sócrates, a areté não está embebida de nenhum juízo de valor ético, senão explicar a característica que faculta qualquer criatura que possui um érgon. ${ }^{24}$ No entanto, falar em uma areté da alma humana implica estabelecer um sentido ético para areté, pois náo será esse o sentido que Sócrates quer dar à justiça como sendo uma areté da alma: dizer que a justiça é boa para a alma e proporciona o bem para aquele que tem a justiça na alma. Portanto, as implicaçóes éticas envolvendo a areté da alma não podem ser explicadas pela mesma relação exposta no argumento, assim como em momento algum a justiça foi definida como areté da alma, conforme Sócrates dá a entender que eles teriam anteriormente concordado ( $\sigma v v \varepsilon \chi \omega \rho \eta ́ j \sigma \alpha \mu \varepsilon v)$ (Rep., 353e7). Também foi dito em passagem anterior que a injustiça possui um érgon (Rep., 351d8): teria ela também uma arete? Se sim, como pode ser uma kakia? Se seguirmos

\footnotetext{
${ }^{24}$ Ver Guthrie (2007, n. 68, p. 87-88): “Areté, comumente traduzido assim (virtude), mas não tendo necessariamente as implicaçōes morais que se costumam ligar com 'virtude'. Significa a excelência característica que faculta qualquer criatura, órgão ou instrumento realizar sua função específica. Em 353a-b, Sócrates fala de areté de olhos e ouvidos: até uma faca a tem se é bem desenhada e aguda. Imediatamente depois disso, Trasímaco concorda com Sócrates em que ele chamaria o tirano injusto de "sensato e bom", usando o adjetivo agathós que corresponde a areté. Não precisa estar envolvido nenhum juízo moral, embora Sócrates o tome na esfera moral acrescentando palavras como kalón e aischrón, e Trasímaco inadvertidamente concorda."
} 
a definição de Sócrates de que tudo aquilo organizado para um érgon tem consequentemente uma areté (Rep., 353a-b), a injustiça, por ter um érgon, também teria uma areté, segundo bem queria provar Trasímaco. Isso permitiria a escolha do governo injusto como uma escolha adequada e sábia para o seu governante. Tal relação não é suficiente para sustentar a justiça como areté da alma, impedindo a decorrente implicação dos érga da alma de superinten-

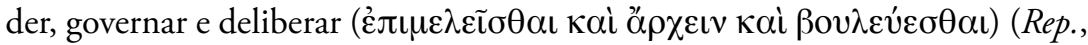
$353 \mathrm{~d})^{25}$ à justiça.

O que fizemos, neste trabalho, foi uma modesta apresentação das teses de Trasímaco, incluindo uma posterior análise das mesmas, mostrando como ele direciona seus argumentos para responder às refutaçóes de Sócrates. Para tal, utilizamos os principais estudos sobre o assunto, com o intuito de elaborar uma exposição adequada dos problemas inseridos na discussão. No encaminhamento da discussão, arriscamos algumas hipóteses que tentam responder às passagens onde Trasímaco se cala, no esforço de dar força ao seu lógos e relevância para as questôes relativas à justiça.

Ao final do Livro I, o próprio Sócrates demonstra estar insatisfeito com o resultado do debate. Dizendo-se glutão, acaba por não conseguir saber o que é a justiça, se ela é uma virtude ou não, e se quem a possui é ou não feliz (Rep., 354b-c). Apesar da estrutura aporética exposta no final do primeiro livro, a discussão entre Sócrates e Trasímaco trouxe problemas importantes a serem resolvidos. A determinação do tipo de governante que uma pólis deve ter é um ponto importante, dentro do campo da filosofia política. A disputa entre os argumentos de Sócrates e Trasímaco levou-nos a duas possibilidades para a téchne do governante: (i) o governante é aquele que age pela justiça visando, com isso, à conveniência dos governados; (ii) o governante seria aquele que governaria em benefício próprio, agindo na mais completa injustiça e dominando os justos, os quais devem obedecê-lo por ser ele o mais forte.

Dessa forma, Trasímaco traz uma importante contribuição para o debate, que é a identificação do tirano: ele é o mais injusto dos homens; e Sócrates irá concordar com isso. $\mathrm{O}$ que ele não admitirá é que a tirania possa levar à máxima felicidade os homens que conseguem realizá-la, o que desvela

\footnotetext{
${ }^{25}$ Enfatiza Robinson (2007, p. 76-77): "Aplicar a noção de 'justiça' a todos esses aspectos da alma no

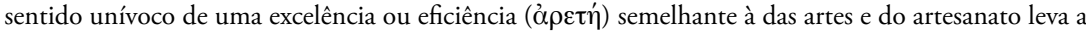
uma incoerência e vimos como, de fato, Sócrates vacila. O dilema é o seguinte: se a justiça é exatamen-

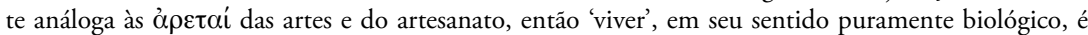
dificilmente uma função da alma, e se 'viver', em seu sentido biológico, é uma função da alma, então a

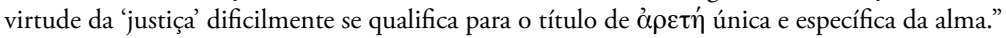


outra consequência do debate, que é de conscientizar-nos para a necessidade da identificação de uma areté. Lembremos que o próprio Trasímaco tentou persuadir Sócrates de que a injustiça deveria ser tomada como uma areté (Rep., 348e; 349a). Isso faz do momento da discussão em questáo ainda incerto quanto à definição da justiça como uma areté em si mesma e da injustiça como uma kakía em si mesma. Enquanto o problema da areté ficar em aberto e a justiça não garantir para si um lugar como verdadeira virtude, a consistência das teses de Trasímaco e a existência do governante completamente injusto serão possíveis. É nesse ponto que devemos frisar as colocações de Trasímaco e as dificuldades ao governo, na inserçáo de um governante injusto que controle a pólis para sua própria conveniência.

Se Trasímaco é inconsistente em sua tese, por que Sócrates não aponta isso? Seria a inconsistência de Trasímaco uma inconsistência em Platão? Não acreditamos nisso. Nem Sócrates nem Trasímaco conseguem defender suas posições. "Os esforços de Sócrates somente silenciaram Trasímaco, mas não refutaram seu argumento para a injustiça." (DOBBS, 1985, p. 813). Prova disso é que o legado de Trasímaco será retomado pelos irmãos Gláucon e Adimanto, os quais, insatisfeitos com a argumentação de Sócrates e com a fácil desistência de Trasímaco, darão fôlego à discussão que se desenrolará nos demais livros da obra. Em momento algum Gláucon aponta para uma inconsistência em Trasímaco, entendendo que a necessidade de renovar Trasímaco (Rep., 358c) seria no intuito de reforçar seu argumento. Adimanto, em sua argumentação, irá citar Trasímaco quase que literalmente, quando pede a Sócrates para elogiar corretamente a justiça, porque, do contrário, seria acusado de concordar "com Trasímaco que a justiça é um bem alheio, isto é, a conveniência do mais forte, enquanto a injustiça é conveniente e vantajosa a si própria, mas prejudicial ao mais fraco.” (Rep., 367c2-5). Se tomássemos a tese de Trasímaco sobre o governo como inconsistente, tornaríamos também inconsistentes os argumentos de Gláucon e Adimanto, pois, apesar de eles apresentarem argumentos diferentes do de Trasímaco, partiriam de um princípio inconsistente, ao retomarem Trasímaco, o que tornaria desnecessária a resposta de Sócrates ao desafio dos irmãos.

Há uma força no argumento de Trasímaco, quando ele demonstra que existe um tipo de "saber fazer" político de sua época, o qual permitirá a consolidação do governo injusto, o que será fortemente questionado por Sócrates. Esse questionamento ocasionará uma investigação mais acurada pelo conceito de governo, de modo que possa abranger todas as questóes envolvidas no 
fazer político e nas coisas da cidade. Trasímaco, portanto, irá nos apresentar um realismo político em que o governo é a representação da conveniência do governante, de maneira que a determinação da justiça se faz para o benefício do próprio governante, em detrimento dos governados. $\mathrm{O}$ tirano aparece em Trasímaco como um desafio para a própria filosofia política, que, para dar uma resposta coerente para o bom governo, deve antes refutar a possibilidade do tirano como sendo o mais feliz dos governantes.

MENEZES, L. M. B. R. Thrasymachus and the téchne of government. Trans/formlaçäo, Marília, v. 42, n. 2, p. 9-30, Abr./Jun., 2019.

ABSTRACT: By associating government with téchne, Thrasymachus states that government requires specific knowledge. This knowledge allows the ruler to benefit from the governed and to take advantage of them. In his definition of government, he equates this téchne with government by an unjust ruler, specifically that of a tyrant. This article aims to analyze the relevance of Thrasymachus' arguments for political philosophy.

KeYwords: Thrasymachus. Socrates. Government. Téchne. Political philosophy.

\section{REFERÊNCIAS}

ADAM, J. The Republic of Plato. Edited with crtical notes commentary and appendices by James Adam. Cambridge: Cambridge University Press, 2009. 2v. (Primeira edição publicada em 1902).

ALLAN, D. J. Plato: Republic book I. London, 1940.

ARAÚJO, C. M. B. O poder e o possivel - dúvauı na República de Platäo. 2005. Tese (Doutorado em Filosofia) - UFRJ, Rio de Janeiro, 2005.

BARNEY, R. Socrates' Refutation of Thrasymachus. In: SANTAS, G. (ed.). The Blackwell guide to Plato's Republic. Malden: Blackwell, 2006. p. 44-62.

BLOOM, A. The Republic of Plato. Traduçáo de Allan Bloom. New York: Basic Books, 1991. (Primeira edição publicada em 1968).

BORDES, J. Politeia dans la pensée grecque jusqu'a Aristote. Paris: Les Belles Lettres, 1982.

BOTER, G. J. Thrasymachus and П $\mathrm{EONE \Xi IA.} \mathrm{Mnemosyne,} \mathrm{v.} \mathrm{39,} \mathrm{n.} \mathrm{3/4,} \mathrm{p.} \mathrm{261-281,}$ 1986. 
CAMPESE, S. Misthotike. In: VEGETTI, M. (Ed.). Platone. La Repubblica, v. I, Napoli: Bibliopolis, 2010. p. 257-268.

CHANTRAINE, P. Dictionnaire étymologique de la langue grecque: histoire de Mots, tome III. Paris: Klincksieck, 1979.

CHAPPELL, T. D. J. The virtues of Thrasymachus. Phronesis, v. 38, n. 1, p. 1-17, 1993.

. Thrasymachus and definition. Oxford Studies in Ancient Philosophy, v. 18, p. 101$107,2000$.

DOBBS, D. The justice of Socrates' philosopher kings. American Journal of Political Science, v. 29, n. 4, p. 809-826, 1985.

DORTER, K. Socrates' Refutation of Thrasymachus and treatment of virtue. Philosophy \& Rhetoric, v. 7, n. 1, p. 25-46, 1974.

EVERSON, S. The incoherence of Thrasymachus. Oxford Studies in Ancient Philosophy, v. 16, p. 99-131, 1998.

FISSELL, B. Thrasymachus and the order of pleonexia. Aporia, v. 19, n. 1, p. 35-43, 2009.

FLEW, A. G. N. Responding to Plato's Thrasymachus. Philosophy, v. 70, n. 273, p. 436447, 1995.

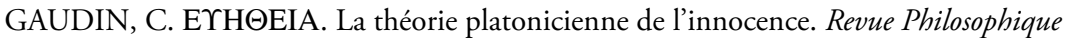
de la France e de l'Étranger, v. 171, n. 2, p. 145-168, 1981.

GUINSBURG, J. A República de Platão. Organização e Tradução de J. Guinsburg. Rio de Janeiro: Perspectiva, 2006.

GUTHRIE, W. K. C. Os sofistas. São Paulo: Paulus, 2007 (Primeira edição em 1995).

HADGOPOUlOS, D. J. Thrasymachus and legalism. Phronesis, v. 18, n. 3, p. 204208, 1973.

HARLAP, S. Thrasymachus' justice. Political Theory, v. 7, n. 3, 347-370, 1979.

HARRISON, E. L. Plato's manipulation of Thrasymachus. Phoenix, v. 21, n.1, p. $27-$ 39, 1967.

HENDERSON, T. Y. In defense of Thrasymachus. American Philosophical Quarterly, v. 7, n. 3, p. 218-228, 1970.

HOURANI, G. F. Thrasymachus' definition of justice in Plato's Republic. Phronesis, v. 7 , n. 2, p. 110-120, 1962.

JAEGER, W. Paidéia. Tradução de Artur M. Parreira. São Paulo: Martins Fontes, 2003.

JANG, I. H. Socrates' refutation of Thrasymachus. History of Political Thought, v. 18, n. 2, p. 189-206, 1997.

JOSEPH, H. W. B. Knowledge and the good in the Republic. Westport, Connecticut: Greewood, 1948. 
Plato's Republic: the argument with Thrasymachus. In: IRWIN, T. H. (ed.). Classical Philosophy: collected papers, v. 3 - Plato's ethics. New York, London: Garland, 1995. p. 21-40.

KERFERD, G. B. The doctrine of Thrasymachus in Plato's Republic. Durham University Journal, v. 40, p. 19-27, 1947; reimpresso in: CLASSEN, C. J. Sophistik. Wege der Forschung, band 187, Darmstadt, 1976. p. 545-563.

. The sophistic movement. Cambridge: Cambridge University Press, 1981.

. Thrasymachus and justice: a reply. Phronesis, v. 9, n. 1, p. 12-16, 1964.

KLOSKO, G. The technical conception of virtue. Journal of the History of Philosophy, v. 19, n.1, p. 95-102, 1981.

. Thrasymachos' Eristikos: the Agon Logon in Republic I. Polity, v. 17, n. 1, p. 5-29, 1984.

LIDDELL, H. G.; SCOTT, R. Greek-English Lexicon. 2. ed. New York: Harper \& Brothers, 1883.

LIMA, P. B. Progymnasia Basileias: l'impero persiano e l'immagine pastorale nella riflessione politica antica. In: PANI, M. (a cura di). Epigrafia e territorio: politica e società. Bari: Edipuglia, 2007. p. 273-289.

MAGUIRE, J. P. Thrasymachus - or Plato? Phronesis, v. 16, n. 2, p. 142-163, 1971.

NICHOLSON, P. P. Unravelling Thrasymachus' arguments in the republic. Phronesis, v. 19, n. 3, p. 210-232, 1974.

PENNER, T. Thrasymachus and the $\dot{\omega} \varsigma \dot{\alpha} \lambda \eta \theta \tilde{\omega} \varsigma$ Ruler. Skepsis, v. 20, p. 206-7, 2009.

PEREIRA, M. H. R. A República. Tradução de Maria Helena da Rocha Pereira. 9. ed. Lisboa: Fundação Calouste Gulbenkian, 2001.

REEVE, C. D. C. Glaucon's challenge and Thrasymacheanism. Oxford Studies in Ancient Philosophy, v. 34, p. 69-103, 2008.

. Goat-stags, philosopher-kings, and eudaimonism. Proceedings of the Boston Area Colloquium in Ancient Philosophy, v. 22, p. 185-209, 2006.

. Philosopher-kings: the argument of Plato's Republic. Indianapolis; Cambridge: Hackett, 2006 (Primeira edição publicada em 1988).

. Socrates meets Thrasymachus. Archiv für Geschichte der Philosophie, v. 67, n. 3, p. 246-265, 1985.

ROBINSON, T. M. A psicologia de Platão. Tradução de Marcelo Marques. São Paulo: Loyola, 2007.

ROOCHNIK, D. Of Art and wisdom: Plato's understanding of techne. Pennsylvania: The Pennsylvania State University Press; University Park, 1996. 
. Socrates's use of the techne-analogy. Journal of the History Philosophy, v. 24, n. 3, p. 295-310, 1986.

SANTAS, G. Understanding Plato's Republic. Oxford: Wiley-Blackwell, 2010.

SLINGS, S. R. Platonis Rempvblicam, recognovit brevique adnotatione critica instrvxit: S. R. Slings. Oxford: Oxford University Press, 2003.

SPARSHOTT, F. E. An Argument for Thrasymachus. Apeiron, v. 21, n. 1, p. 55-67, 1988.

. Socrates and Thrasymachus. The Monist, v. 50, n. 3, 421-459, 1966.

STRAUSS, L. The city and man. Chicago, London: University of Chicago Press, 1964.

VEGETTI, M. Platone. La Repubblica, v. 1. Traduzione e commento a cura di Mario Vegetti. Napoli: Bibliopolis, 1998.

. Techne. In: PLATONE. La Repubblica. Traduzione e commento a cura di Mario

Vegetti. Napoli: Bibliopolis, 1998. p. 193-207. V.1.

. Trasimaco. In: PLATONE. La Repubblica. V. I. Traduzione e commento a cura di Mario Vegetti. Napoli: Bibliopolis, 1998. p. 233-256. V. 1.

WELTON, W. A. Thrasymachus vs. Socrates: what counts as a good answer to the question 'What is Justice'? (Republic 336b-9b). Apeiron, v. 39, n. 4, p. 293-317, 2006.

ZUCKERT, C. Why Socrates and Thrasymachus become Friends. Philosophy and Rhetoric, v. 43, n. 2, p. 163-185, 2010.

Recebido: 30/08/2017

Aceito: $29 / 11 / 2018$ 
MENEZES, L. M. B. 